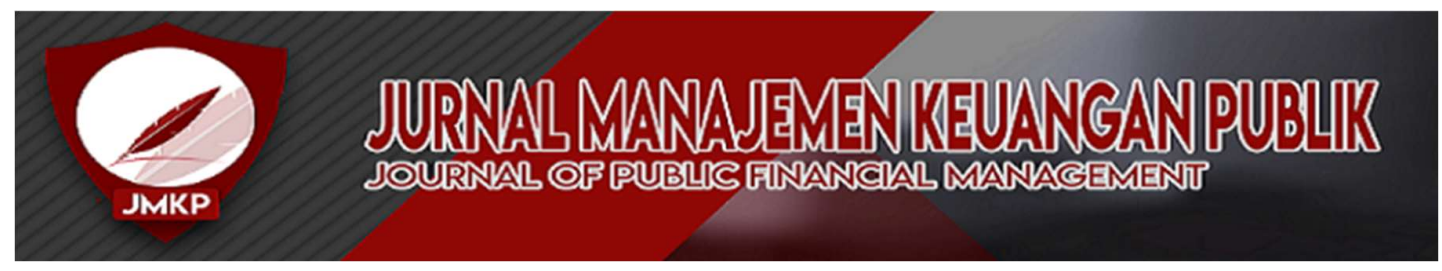

\title{
THE INFLUENCE OF CORPORATE GOVERNANCE, CAPITAL STRUCTURE, AND COMPANY SIZE ON THE COMPANY'S FINANCIAL PERFORMANCE
}

\author{
Muhammad Abdul Izzatur Rahman ${ }^{1}$ \\ PKN STAN, Indonesia \\ rahman.alfarid@gmail.com \\ Subagio $^{2}$ \\ PKN STAN, Indonesia \\ subagio@pknstan.ac.id
}

\section{ABSTRACT}

This study aims to examine the effect of the implementation of corporate governance, capital structure, and firm size on the financial performance of banking companies. The implementation of good corporate governance is an obligation that must be carried out by companies which already have guidelines from the Financial Services Authority and other institutions. In fact, not all companies have applied good governance even though it can improve the performance of the company so it becomes interesting to study the impact of good governance implementation in Indonesia. This study uses panel data regression analysis with research samples from banking companies listed on the Indonesia Stock Exchange (IDX) from 2017 to 2019. The results of the study as overall show that corporate governance, capital structure and firm size have a positive effect on the company's financial performance. Managerial ownership as corporate governance proxy has a significant positive impact on financial performance partially.

Keywords: bank, capital structure, corporate governance, company size

Klasifikasi JEL: G21, G34, 


\section{INTRODUCTION}

\subsection{Background}

Every company basically has a goal to increase the value of its company by doing the best possible performance. This is continuously done because the value of the company can reflect the quality of the company and these points are highly considered by the shareholders as owners of the company. Company shareholders as company owners want managers as agents or their extensions to work well and as much as possible in order to prosper their principals, but agents also have a desire to fulfill their respective interests according to agency theory in research conducted by Jensen and Meckling (1976) along with their efforts to prosper the company.

Performance measurement of a company can be monitored based on the company's strategy, implementation, and execution that contribute to increasing company profits according to Kaplan and Norton (2005). The financial performance of a company can also be measured using financial ratios or other approaches such as the market value of the company's stock, profitability ratios, liquidity ratios, and solvency ratios. Investors can also assess the company in terms of Good Corporate Governance. Good corporate governance will provide a sense of security to creditors and shareholders and have an impact on increasing the trust of creditors and shareholders for their investments in the company (Nugroho and Suhendro, 2021). The application of the principles of Good Corporate Governance within the company also makes it possible to prevent fraud and abuse of authority from the management and directors within the company.
Based on research conducted by Mahiswari and Nugroho (2016), Enda and Tenaya (2017), Yuniarti and Syaichu (2018), Lisandri and Hayati (2019), Dika and Wirawati (2020), Churniawati et al (2020), Machmud et al (2020), Ali et al (2021), there are several corporate governance proxies that can be used in research to examine the principles or characteristics of Good Corporate Governance. These proxies include managerial ownership, institutional ownership, size of the board of directors, size of the board of commissioners, duality of CEO and audit committee.

The financing decision of a company will involve various company policy issues. Financing decisions will refer to other company policies related to investment and company value because the optimal capital structure and representing the level of company financing can basically maximize the market share price and company value. The management of the company will always strive for an optimal rate of return or return in order to maintain the interests of shareholders as stakeholders in order to always obtain profits, so that the company will always be projected to have an optimal capital structure. A company can be assessed as an insolvable company if there is a possibility that the assets owned by the company cannot pay all the debts and obligations of the company (Churniawati et al, 2020). According to Foyeke et al (2015), the size of the company can determine the shareholder base as well as the business capital base which informs the level of stewardship expected of the company's managers and the board of directors.

According to the report which be held by the CG Watch in 2018 and 2020, the assessment of scores for the country of Indonesia from 2018 to 2020 experienced anomalies. When comparing 
the scores of Indonesia with the assessment scores of eleven other countries that were also assessed, only Indonesia that experienced a decline in scores during that period. Based on a report from CG Watch in 2018, the score for Indonesia in 2018 was 34 points (CG Watch, 2018). Indonesia was in the lowest position that year. In the $2020 \mathrm{CG}$ Watch report, the assessment score for Indonesia in 2020 dropped to 33.6 points (CG Watch, 2020). This indicates that there has been a decline in the level of Good Corporate Governance in Indonesia during that period.

Based on this phenomenon, this study was conducted to determine the effect of corporate governance in banking companies with managerial ownership and institutional ownership as a proxy approach and also associated with the effect of firm size and capital structure.

\subsection{Literature Review and Hypothesis Development}

According to agency theory, shareholders in a public company will act as principals, while the agent who is delegated authority by the principal is the Executive Director. Shareholders in this case employ the Executive Director to act in accordance with the interests of the principal (Mahiswari and Nugroho, 2016) even though the agent does not always carry out his duties exactly as expected by the shareholders. Company owners or company shareholders want managers as agents to work well and as much as possible in order to prosper their principals, but agents also have a desire to fulfill their personal interests humanely. (Yuniarti and Syaichu, 2018). Kaplan and Norton (2005) explain that the measurement of financial performance can be indicated based on the level of strategy, implementation, and execution of the company that contributes to increasing company profits. The definition of IAI (2007) for financial performance is the ability of a corporation or company to manage and control its resources.

The definition of good corporate governance according to the British Cadbury Committee in the Cadbury Report (1992) is a set of rules that determine the relationship between stakeholders, managers, creditors, government, employees and other stakeholders both external and internal parties with regard to rights and responsibilities, or the system by which the company is controlled and directed. According to UNESCAP (2004), there are eight principles of good governance, namely Participatory, Rule of Law, Transparency, Responsiveness, Consensus Oriented, Equity and Inclusiveness, Effectiveness and Efficiency, and Accountability. Referring to the Financial Services Authority Regulation Number 55/POJK.03/2016 concerning the Implementation of Governance for Commercial Banks, Good Corporate Governance applies five principles, namely the principle of transparency, the principle of accountability, the principle of responsibility, the principle of independence, and the principle of fairness.

Weston and Copeland (1997) explained that the definition of capital structure is the ratio or level of proportion between long-term debt and equity. Capital structure can be interpreted as a policy of determining the funding structure of a company related to debt and the company's own capital. Corporate capital financing decisions involve a variety of policy issues. These decisions affect the capital structure, corporate 
governance and development of the company (Green et al, 2002). According to Titman et al (2014), capital structure is a combination of long-term funding sources used by the company. Companies that have an optimal capital structure will produce an optimal rate of return (Brigham and Houston, 2006, cited in Tambunan and Prabawani, 2018).

Jensen and Meckling (1976) state that large companies tend to have higher agency costs than small companies. Foyeke et al (2015) also states that the size of a company can affect customer loyalty, supervision and responsiveness to stakeholders. Suwito and Herawaty (2005) explained that company size is the grouping of a company into several groups based on the total value of the company's assets. Investors can assess the size of a company by comparing the asset value of a company with the asset value of other similar companies.

Based on previous research conducted by Dika and Wirawati (2020), Yuniarti and Syaichu (2018), Enda and Tenaya (2017) and Mahiswari and Nugroho (2016), managerial ownership has no effect on Return on Assets, while research from Lisandri and Hayati (2019) get results that have a positive effect. Share ownership by managers can minimize agency problems whose direct impact is to reduce agency costs so that there is an increase in the return obtained. Based on this description, the first hypothesis proposed is as follows:

H1: Managerial Ownership has a significant effect on Return on Assets

According to Churniawati et al (2020), Dika and Wirawati (2020) and Situmorang and Simanjuntak (2019), institutional ownership has no effect on Return on Assets. Different results were obtained from research conducted by Ali et al (2021), Machmud et al (2020), Lisandri and Hayati (2019), Mahiswari and Nugroho (2016) whose test results have a significant positive effect. Research from Yuniarti and Syaichu (2018) and Enda and Tenaya (2017) also obtained different results, namely institutional ownership has a negative effect. Institutional ownership in a company will have an impact on the supervision of the company's operations on the management of the institutional shareholders. One of the impacts is related to decision making which is believed to be more effective so as to improve company performance. Based on this description, the second hypothesis proposed is as follows:

$\mathrm{H} 2$ : Institutional Ownership has a significant effect on Return on Assets

Research from Machmud et al (2020) and Kristianti (2018) obtained research results that capital structure has a positive influence, while different results were obtained by Anthonie et al (2018) which shows that the capital structure has a negative effect. The results of research from Tambunan and Prabawani (2018), Anggraini and Ruzikna (2017) state that capital structure has no effect on financial performance. The capital structure shows the proportion of debt used in financing or financing investments, so that investors can obtain information regarding the risk and rate of return on investment by knowing the structure. Based on this description, the third hypothesis proposed is as follows:

H3: Capital structure has a significant effect on Return on Assets

Based on the results of research conducted by Nugroho and Suhendro (2021) and Enda and Tenaya (2017), firm size has a positive effect, while research conducted by Tambunan and Prabawani (2018), Yuniarti and Syaichu (2018), and Mahiswari and Nugroho (2016) get no effect. Many or at least fraudulent 
practices that damage financial performance and are carried out by companies can be determined from the size of the company because relatively large companies are known for their performance by the public more than small companies so that the company will try to publish its financial condition more carefully. Based on this description, the fourth hypothesis proposed is as follows:

H4: Firm size has a significant effect on Return on Assets

\section{METHODS}

This research is a quantitative method, using secondary data in the form of reports published by the Indonesia Stock Exchange. The research object as well as the research population are all banking sector companies listed on the Indonesia Stock Exchange in 2017-2019. The study used panel data regression analysis and sample selection using purposive sampling technique based on specified criteria.

The independent variables used in this study are Managerial Ownership, Institutional Ownership, Debt to Equity Ratio, and Company Size. Managerial ownership is the portion of company share ownership by managers in a company. The proxy formula based on research from Dika and Wirawati (2020) is as follows:

Managerial Ownership $=\frac{\text { Manager share ownership }}{\text { Total Company's Share }} \times 100 \%$

Institutional ownership is defined as the portion of company ownership by another institution in a company. The proxy formula based on research from Dika and Wirawati (2020) is as follows:

Institutional Ownership $=\frac{\text { Institutional share ownership }}{\text { Total Company's Share }} \times 100 \%$
Capital structure is the ratio or level of proportion between long-term debt and capital (Weston and Copeland, 1997). The capital structure proxy used in this study is the Debt to Equity Ratio variable based on research from Machmud et al. (2020) as follows:

Debt to Equity Ratio $=\frac{\text { Total Liabilities }}{\text { Total Equity }}$

Company size is the total asset value of the company. The formula of the proxy based on Mahiswari and Nugroho (2016) is as follows:

Company Size $=$ Ln $x$ Total Assets

The dependent variable used in this study is the company's financial performance. The company's financial performance is a description of the financial condition of a company that reflects work performance in a certain period (Dika and Wirawati, 2020). Financial performance in this study is measured by one of the profitability ratios, namely ROA (Return on Assets) as used in research (Dika and Wirawati, 2020) as follows:

$R O A=\frac{\text { Net Profit after Tax }}{\text { Total Assets }}$

This study examines the effect of the independent variables proxied by Managerial Ownership, Institutional Ownership, Debt to Equity Ratio, and Company Size on the company's financial performance proxied by Return on Assets as the dependent variable with the following model:

$\mathrm{ROA}=\alpha+\beta 1 \mathrm{MGR}+\beta 2 \mathrm{INS}+\beta 3 \mathrm{DER}+$ $\beta 4 \mathrm{SIZE}+\mathrm{e}$

Information:

ROA $=$ Return on Assets

$\alpha=$ Constant 
$\beta=$ Regression coefficient

MGR = Managerial Ownership

INS = Institutional Ownership

DER $=$ Capital Structure

SIZE = Company Size

$\mathrm{e}=$ Residual variable (error rate)

\section{RESULTS AND DISCUSSION}

Descriptive statistics for all variables used in the study are listed in Table 1 as follows.

Table 1. Descriptive Statistics

\begin{tabular}{|l|c|c|c|c|c|}
\hline Variable & Obs & Mean & $\begin{array}{c}\text { Std. } \\
\text { Dev. }\end{array}$ & Min & Max \\
\hline ROA & 120 & 0.005182 & 0.017859 & -0.092324 & 0.031343 \\
\hline MGR & 120 & 0.006178 & 0.026067 & 0.000000 & 0.240000 \\
\hline INS & 120 & 0.722815 & 0.283428 & 0.000000 & 0.999997 \\
\hline DER & 120 & 6.169864 & 3.514651 & 0.939368 & 30,471150 \\
\hline SIZE & 120 & 31,242500 & 1.809249 & 27.222560 & 34,887150 \\
\hline
\end{tabular}

Source: Processed by the author

The independent variable MGR or managerial ownership in 2017 to 2019 has an average value of 0.0061 . This value indicates that the overall percentage of share ownership owned by company managers is $0.6 \%$ of the total shares. The independent variable INS or institutional ownership in 2017 to 2019 has an average value of 0.72281 . This value shows that the overall percentage of share ownership owned by an institution to the company is $72.28 \%$ of the total shares.

The independent variable DER or debt to equity ratio in 2017 to 2019 has an average value of 6.1698 . This value shows that the ratio between the value of the company's debt to the company's equity is $616.98 \%$ of the total equity. The independent variable SIZE or company size in 2017 to 2019 has an average value of 31,242 . The calculation of the value of the SIZE variable uses the natural logarithm so that the average value of the variable does not show the actual size of the company. The dependent variable ROA or Return on Assets in 2017 to 2019 as a whole has an average value of 0.005182 . This value shows that in general the company earns a net profit after tax of $0.5182 \%$ of total assets.

The results of the Skewness/Kurtosis normality test show that the Prob $>$ chi 2 value is below 0.05 , so the data distribution is not normally distributed. According to Gujarati \& Porter (2009), if the number of samples for a study has been above 30 samples or the number of $n>30$, it can use the assumption of the Central Limit Theorem so that the assumption of normality can be ignored. The results of the multicollinearity test show that there is no multicollinearity problem based on the correlation value of each independent variable that does not exceed 0.8 with the lowest value -0.194 for the correlation of managerial ownership and firm size and the highest value of 0.06 for the Debt to Equity Ratio correlation and size company.

The results of the autocorrelation test show the results of Prob $>F$ of 0.3164 so that the regression model is free from autocorrelation problems. The test results from the heteroscedasticity test show the Prob $>$ chi 2 value of 0.0000 so that the regression model is not free from heteroscedasticity. Based on this, the estimation of robust standard errors is used in the following model in Table 2.

Table 2. Regression Model Results

\begin{tabular}{|c|c|c|c|}
\hline Variable & Coefficient & $\mathrm{t}$ & $\mathrm{P}>\mathrm{t}$ \\
\hline MGR & 0.1492258 & 3.33 & 0.002 \\
\hline INS & 0.0071957 & 0.87 & 0.392 \\
\hline DER & -0.0003078 & -1.3 & 0.201 \\
\hline SIZE & -0.026601 & -1.95 & 0.058 \\
\hline
\end{tabular}

Source: Processed using STATA 
The managerial ownership variable (MGR) has a coefficient value of 0.1492258 and a probability value of 0.002 . Based on these results, the hypothesis $\mathrm{H} 0$ is rejected and $\mathrm{H} 1$ is accepted. Thus, the MGR variable positively has a significant effect on ROA. The institutional ownership variable (INS) has a coefficient value of 0.0071957 , and a probability value of 0.392 . Based on these results, the hypothesis $\mathrm{H} 0$ is accepted and $\mathrm{H} 1$ is rejected. Thus, the INS variable partially has no significant effect on ROA.

The variable debt to equity ratio (DER) has a coefficient value of 0.0003078 , and a probability value of 0.201. Based on these results, the hypothesis H0 is accepted and $\mathrm{H} 1$ is rejected. Thus, the DER variable partially does not have a significant effect on ROA. Institutional ownership variable (SIZE) has a coefficient value of 0.02661 , and a probability value of 0.058 . Based on these results, it is known that the value of $\mathrm{P}>|\mathrm{t}|$ greater than the significance value of 0.05 so that $\mathrm{H} 0$ is accepted and $\mathrm{H} 1$ is rejected. Thus, the SIZE variable partially does not have a significant effect on ROA.

Providing opportunities from companies to managers to participate in share ownership has the aim of providing a sense of equality between managers and shareholders in the company so that companies can reduce agency conflicts which will also reduce agency costs. The findings of this study support the results of Lisandri and Hayati's research (2019) but contradict the results of research by Mahiswari and Nugroho (2016), Yuniarti and Syaichu (2018) and Enda and Tenaya (2017). The portion of managerial ownership is believed to be a form of reward for the manager's performance as well as a cheap agency fee to reduce conflicts of interest.

Institutional ownership does not have a significant relationship to the company's financial performance in this study. This finding is in line with the research of Churniawati et al (2020), Dika and Wirawati (2020) and Situmorang and Simanjuntak (2019) but contrary to the research of Ali et al (2021), Machmud et al (2020), Lisandri and Hayati (2019), Mahiswari and Nugroho (2016), Yuniarti and Syaichu (2018) and Enda and Tenaya (2017).

Capital structure also does not have a significant relationship to the company's financial performance in this study. This finding is in line with the research of Tambunan and Prabawani (2018) and Anggraini and Ruzikna (2017) but these results contradict the results of the research of Machmud et al (2020), Kristianti (2018) and Anthonie et al (2018).

Company size is known to have no significant effect on the company's financial performance. The findings are in line with research by Tambunan and Prabawani (2018) and Mahiswari and Nugroho (2016) but contradict the results of research by Nugroho and Suhendro (2021) and Enda and Tenaya (2017).

\section{CONCLUSION}

This study aims to determine the effect of corporate governance represented by managerial ownership and institutional ownership, capital structure, and firm size on the financial performance of companies in the banking sector. The results showed that Managerial Ownership had a significant positive effect on Return on Assets. Giving the proportion of company shares to company managers can reduce 
opportunistic behavior by having equal interests in the company. This is in line with the agency theory by Jensen and Meckling (1976).

Institutional Ownership does not have a significant effect based on statistical data but has a positive direction of change as its value increases. Debt to Equity Ratio also has no significant effect and has a statistically negative direction of change. Firm size has no significant effect and also has a statistically negative direction of change.

Suggestions that can be given from the results of this study for companies are related to the implementation of Corporate Governance, especially managerial ownership in banking companies, which are believed to increase net income. This can be a trigger to reduce conflicts of interest and reduce the company's agency costs so that the company can reach the point of maximum performance. For corporate investors, companies that are recommended to invest are companies whose managerial ownership level is above zero. For relevant Government Agencies, the results of the research can be a reference for what kind of companies are believed to have good performance.

Further research expected to conduct research with a longer time span and add variables such as company age (Age), Return on Equity (ROE), number of boards of directors, and Corporate Social Responsibility (CSR). 


\section{REFERENCES}

Ali, S., Fei, G., Ali, Z., \& Hussain, F. (2021). CORPORATE GOVERNANCE AND FIRM PERFORMANCE: EVIDENCE FROM LISTED FIRMS OF PAKISTAN. Journal on Innovation and Sustainability, 12(1), 170-187. DOI:10.23925/2179-3565.2021v12i1p170-187

Anggraini, N. \& Ruzikna, R. (2017). Pengaruh Struktur Modal Terhadap Kinerja Keuangan Pada Perusahaan Farmasi Yang Terdaftar Di Bursa Efek Indonesia Periode 2010-2014. Doctoral dissertation at Riau University. Retrieved from jom.unri.ac.id/index.php/JOMFSIP/article/view/14362

Anthonie, D. P., Tulung, J. E., \& Tasik, H. H. (2018). Pengaruh Struktur Modal Terhadap Kinerja Keuangan Pada Perbankan Yang Terdaftar Di Bursa Efek Indonesia Periode 2012-2016. Jurnal Riset Ekonomi, Manajemen, Bisnis dan Akuntansi, 6(2). $\quad$ Retrieved from https://ejournal.unsrat.ac.id/index.php/emba/article/view/19537

Cadbury, A. (1992). Report of the Committee on the Financial Aspects of Corporate Governance. London: Gee \& Co.

CG Watch. (2018). Hard Decisions: Asia Faces Tough Choices in CG Reform. Hongkong: ACGA and CLSA Limited.

CG Watch. (2020). Future Promise: Aligning Governance and ESG in Asia. Hongkong: ACGA and CLSA Limited.

Churniawati, A., Titisari, K. H., \& Wijayanti, A. (2020). Pengaruh good corporate governance, leverage dan firm size terhadap kinerja keuangan. PROCEEDING SEMINAR NASIONAL AKUNTANSI (Vol. 2, No. 1). Retrieved from http://openjournal.unpam.ac.id/index.php/SNU/article/view/2629

Dika P. G., \& Wirawati, N. (2020). Pengaruh Good Corporate Governance pada Nilai Perusahaan dengan Kinerja Keuangan sebagai Variabel Mediasi. E-Jurnal Akuntansi, 30(2), 388 - 402. DOI:10.24843/EJA.2020.v30.i02.p09

Enda, P., \& Tenaya, K. A. (2017). PENGARUH PENERAPAN GOOD CORPORATE GOVERNANCE DAN UKURAN PERUSAHAAN TERHADAP KINERJA KEUANGAN PERBANKAN YANG TERDAFTAR DI BURSA EFEK INDONESIA PERIODE 2013-2016. E-Jurnal Akuntansi, 21(1), 310-329. Retrieved from https://ocs.unud.ac.id/index.php/Akuntansi/article/view/33044

Foyeke, O. I., Iyoha, F. O., \& Ojeka, Stephen. (2015). Firm Size and Financial Performance: A Determinant of Corporate Governance Disclosure Practices of Nigerian Companies. Journal of Accounting and Auditing: Research \& Practice, Vol. 2015 (2015). DOI: 10.5171/2015.467294

Green, C. J., Manos, R., Murinde, V., \& Suppakitjarak, J. (2002). The Impact of Microstructure in Emerging Stock markets: Evidence from Mumbai, India. Final Draft of a Paper Presented at the International conference on Finance \& Development: Evidence and Policy Issues, Nairobi, July (pp. 10-11). Retrieved from https://core.ac.uk/download/pdf/288388822.pdf

Gujarati, D. N. \& Porter, D. C. (2009). Basic Econometrics. 5th Edition. New York: McGraw-Hill Companies. 
Ikatan Akuntan Indonesia. (2007). Standar Akuntansi Keuangan. Jakarta: Salemba Empat.

Jensen, M. C., \& Meckling, W. H. (1976). Theory of the firm: Managerial behavior, agency costs and ownership structure. Journal of financial economics, 3(4), 305360. DOI:10.1016/0304-405X(76)90026-X

Kaplan, R. S., \& Norton, D. P. (2005). The balanced scorecard: measures that drive performance. Harvard business review. 83(7). 172. Retrieved from academia.edu/download/54588379/Kaplan_Nortonbalanced_scorecard.pdf

Kristianti, I. P. (2018). Analisis pengaruh struktur modal terhadap kinerja keuangan perusahaan. Akuntansi Dewantara. 2(1). 56-68. Retrieved from https://core.ac.uk/download/pdf/230381734.pdf

Lisandri, L., \& Hayati, N. (2019). Corporate Governance Terhadap Corporate Financial Performance Melalui Earning Management Sebagai Pemediasi. JURNAL ILMIAH BISNIS dan KEUANGAN, 8(2), 91-103. Retrieved from http://journal.stiei-kayutangi-bjm.ac.id/index.php/jibk/article/view/448

Machmud, M., Ahmad, I. H., Khalik, A., Murfat, M. Z., \& Basalamah, J. (2020). Effect of Capital Structure and Good Corporate Governance on Financial Performance in Manufacturing Companies based on the Indonesia Stock Exchange. IORS Journal of Business and Management, 22(3), 36-49. Retrieved from https://www.academia.edu/download/62472234/E22030536492020032531214-40o9e3.pdf

Mahiswari, R., \& Nugroho, P. (2016). Pengaruh Mekanisme Corporate Governance, Ukuran Perusahaan dan Leverage Terhadap Manajemen Laba dan Kinerja Keuangan. Jurnal Ekonomi dan Bisnis, 17(1), 1-20. DOI:10.24914/jeb.v17i1.237

Nugroho, Ts., \& Suhendro, S. (2021). Analisis Faktor-Faktor yang Mempengaruhi Kinerja Perusahaan Perbankan yang Terdaftar di Bursa Efek Indonesia Periode 2015-2018. Journal of Economics and Business, 5(1), 209-214. DOI:10.33087/ekonomis.v5i1.269

Otoritas Jasa Keuangan. (2016). Peraturan Otoritas Jasa Keuangan (POJK) Nomor 55/POJK.03/2016 tentang Penerapan Tata Kelola Bagi Bank Umum. Jakarta: Otoritas Jasa Keuangan.

Situmorang, C., \& Simanjuntak, A. (2019). PENGARUH GOOD CORPORATE GOVERNANCE TERHADAP KINERJA KEUANGAN PERUSAHAAN PERBANKAN YANG TERDAFTAR DI BURSA EFEK INDONESIA. JURNAL AKUNTANSI DAN BISNIS: Jurnal Program Studi Akuntansi, 5, 160. DOI:10.31289/jab.v5i2.2694.

Suwito, E., \& Herawaty, A. (2005). Analisis Pengaruh Karakteristik Perusahaan Terhadap Tindakan Perataan Laba yang Dilakukan oleh Perusahaan Yang Terdaftar Di Bursa Efek Jakarta. Simposium Nasional Akuntansi VIII. Retrieved from https://www.academia.edu/download/29666337/27208023.pdf

Tambunan, J. T. A., \& Prabawani, B. (2018). Pengaruh Ukuran Perusahaan, Leverage dan Struktur Modal Terhadap Kinerja Keuangan Perusahaan (Studi Pada Perusahaan Manufaktur Sektor Aneka Industri Tahun 2012-2016). Jurnal Ilmu Administrasi Bisnis, 7(2), 130-140. Retrieved from https://ejournal3.undip.ac.id/index.php/jiab/article/view/20329 
Titman, S., Keown, A. J., \& Martin, J. D. (2014). Financial Management: Principles and Applications, 12th Edition. New Jersey: Pearson Education, Inc.

UNESCAP (2004). Human settlements: What is good governance. Manila: ESCAP. Available from https://www.unescap.org/resources/what-good-governance

Weston, F. J., \& Copeland, T. E. (1997). Financial Management Vol. 2 Issue 9. Jakarta: Binarupa Aksara.

Yuniarti, M., dan Syaichu, M. (2018). PENGARUH GOOD CORPORATE GOVERNANCE TERHADAP KINERJA PERUSAHAAN MANUFAKTUR DI INDONESIA YANG TERDAFTAR DI BEI. Diponegoro Journal of Management, 7(4), 561-573. Retrieved from https://ejournal3.undip.ac.id/index.php/djom/article/view/2248 